\title{
Urgensi Kompetensi Guru Dalam Pembelajaran Alquran Di Raudhatul Athfal Kota Medan
}

\author{
Halimatusssa'diyah Lubis*1 \\ Universitas Muhammadiyah Sumatera Utara*1 \\ ${ }^{*}$ email:mirzaramadhanlubis07@ gmail.com
}

\begin{abstract}
This study aims to determine the activities of the Ministry of Religion in Medan in order to improve and strengthen teacher competence in teaching the Koran, related to learning planning, learning methods used, obstacles encountered, and efforts made by teachers in overcoming obstacles in teaching the Koran in Raudhatul Athfal City of Medan. The research method used is qualitative research The data collection techniques are interviews, observation, documentation study. Then, data management consists of data reduction, data display/data presentation, data analysis, techniques guaranteeing the validity of research results. The results of the study revealed that the activities of the Ministry of Religion in Medan in increasing teacher competence in teaching the Koran in Raudhatul Athfal Medan City, were pursued by carrying out programs to improve teacher education qualifications, integrated competency-based training programs, educational supervision programs and teacher training empowerment programs, carried out continuously. Learning planning conducted by Raudhatul Athfal teacher in teaching Alquran in Raudhatul Athfal Medan City, namely planning for compiling or organizing learning materials that will be given / taught to students consisting of (1) planning for Semester Program (PROMES), (2 ) Weekly Learning Implementation Plan (RPPM), (3) Daily Learning Implementation Plan (RPPH), and (4) Standard Operating Procedure (SOP). The Koran Learning Method used by teachers in general in the city of Medan, namely using the Iqro method 'which consists of letter recognition, harakah recognition, letter connection, short length recognition, and sentence recognition, recognition of waqaf signs.
\end{abstract}

Keywords: Teacher Competence, Koran Learning.
Artikel Info

Received:

02 April 2020

Revised:

20 April 2020

Accepted:

02 June 2020

Published:

04 June 2020 


\section{Abstrak}

Penelitian ini bertujuan untuk mengetahui aktiftas Kementerian Agama Kota Medan guna meningkatkan dan memperkuat kompetensi guru dalam mengajarkan Alquran, terkait perencanaan pembelajaran, metode pembelajaran yang digunakan, hambatan yang dihadapi, dan usaha yang dilakukan guru dalam mengatasi hambatan dalam mengajarkan Alquran di Raudhatul Athfal Kota Medan. Metode penelitian yang digunakan adalah penelitian kualitatif Adapun teknik pengumpulan datanya adalah wawancara, observasi, studi dokumentasi. Kemudian pengelolaan data terdiri dari reduksi data, display data/penyajian data, analisis data, teknik menjamin keabsahan hasil penelitian. Hasil penelitian menunjukkan bahwa aktifitas Kementerian Agama Kota Medan dalam meningkatkan kompetensi guru dalam mengajarkan Alquran di Raudhatul Athfal Kota Medan, ditempuh dengan melakukan program peningkatan kualifikasi pendidikan guru, program pelatihan terintegrasi berbasis kompetensi, program supervisi pendidikan dan program pemberdayaan musyawarah guru, yang dilakukan secara berkesinambungan. Perencanaan pembelajaran yang dilakukan guru Raudhatul Athfal dalam mengajarkan Alquran di Raudhatul Athfal Kota Medan, yaitu perencanaan penyusunan atau pengorganisasian bahan-bahan pembelajaran yang akan diajarkan kepada siswa yang terdiri dari (1) rencana penyusunan Program Semester (PROMES), (2) Rencana Pelaksanaan Pembelajaran Mingguan (RPPM), (3) Rencana Pelaksanaan Pembelajaran Harian (RPPH), dan (4) Standar Operasional Prosedur (SOP). Adapun Metode Pembelajaran Alquran yang digunakan guru secara umum di kota Medan, yaitu menggunakan metode Iqro' yang terdiri dari pengenalan huruf, pengenalan harakah, penyambungan huruf, pengenalan panjang pendek, dan pengenalan kalimat, pengenalan tanda waqaf.

Kata Kunci: Kompetensi Guru, Pembelajaran Alquran.

\section{A. Pendahuluan}

Dalam penyelenggaraan pendidikan suatu keberhasilan dapat dicapai dengan dukungan berbagai komponen di antaranya komponen guru, komponen peserta didik, komponen pengelolaan, dan komponen pembiayaan. Kesemua komponen itu, saling berkaitan satu sama lainnya dan sangat menentukan bagi keberhasilan penyelenggaraan pendidikan dalam mencapai tujuannya. Guru adalah diantara unsur di bidang kependidikan yang harus berperan secara aktif dan menempatkan kedudukannya sebagai 
INTIQAD: JURNAL AGAMA DAN PENDIDIKAN ISLAM

ISSN 1979-9950 (print) || ISSN 2598-0033 (online), http://jurnal.umsu.ac.id/index.php/intiqad

DOI: 10.30596/intiqad.v12i1.4650

Vol. 12, No. 1 (June 2020)

tenaga pendidik dan pengajar profesional sesuai dengan tuntutan masyarakat yang semakin berkembang.

Seorang guru tidak semata-mata sebagai pengajar yang melakukan transfer ilmu pengetahuan, tetapi juga sebagai pendidik yang melakukan transfer nilainilai sekaligus sebagai pembimbing yang mengarahkan dan menuntun siswa dalam belajar. Kelengkapan dari jumlah tenaga pengajar dan kualitas dari guru tersebut akan mempengaruhi keberhasilan siswa dalam belajar yang berujung pada peningkatan mutu pendidikan. Untuk itu setiap guru dituntut agar profesional dalam menjalankan tugasnya.

Diantara standar yang memegang peran penting dalam operasional pendidikan di sekolah adalah standar pendidik dan tenaga kependidikan. Adapun yang dimaksud dengan tenaga kependidikan terdiri atas guru, pengelola satuan pendidikan, pengawas, peneliti dan pengembangan di bidang pendidikan, pustakawan, laboratorium, teknisi sumber belajar dan penguji (Rivai \& Murni, 2010).

Profesionalitas dan kualitas kerja para guru tersebut merupakan salah satu faktor penting yang sangat dibutuhkan oleh sekolah untuk mencapai tujuan pendidikan. Profesionalitas dan kualitas kerja para guru juga merupakan indikasi dari adanya komitmen guru terhadap sekolah sebagai suatu organisasi tempatnya mengajar, sehingga dapat dikatakan seorang guru yang memiliki komitmen terhadap sekolah tempatnya mengajar akan berusaha bekerja dengan sungguh-sungguh untuk mewujudkan tujuan yang ingin dicapai.

Untuk itu, diperlukan pembinaan secara berkelanjutan kompetensi guru guna peningkatan kemampuan atau kinerja dalam melaksanakan tugasnya di sekolah. Sutisna menegaskan bahwa pengawasan atau supervisi sebagai segala usaha pejabat dalam memimpin guru-guru dan tenaga kependidikan lain, untuk memperbaiki pengajaran, termasuk menstimulasi, menyeleksi pertumbuhan dan perkembangan jabatan guru-guru, menyeleksi dan merevisi tujuan-tujuan pendidikan, bahan dan metode serta evaluasi pembelajaran (Sutisna, 2003).

Lima tahun terakhir ini kondisi kompetensi guru Raudhatul Athfal di Kota Medan, terutama dalam mengajarkan mata pelajaran Alquran mengalami penurunan. Berdasarkan hasil observasi yang dilakukan terhadap beberapa Raudhatul Athfal di kota Medan ditemukan bahwa kemampuan guru Raudhatul Athfal dalam mengajarkan Alquran masih kurang. Hasil observasi 
INTIQAD: JURNAL AGAMA DAN PENDIDIKAN ISLAM

ISSN 1979-9950 (print) || ISSN 2598-0033 (online), http://jurnal.umsu.ac.id/index.php/intiqad

DOI: 10.30596/intiqad.v12i1.4650

Vol. 12, No. 1 (June 2020) terhadap guru-guru Alquran di beberapa

Raudhatul Athfal di kota Medan terlihat banyak yang belum belum memenuhi kompetensi sebagaimana mestinya.

Raudhatul Athfal Ulumul Quran Jl.

Bahagia Teladan Kecamatan Medan Area dan Raudhatul Athfal Iqro' Jl. PLTU Sicanang Belawan diberikan kewenangan mengajarkan mata pelajaran Alquran, sementara kompetensinya dalam penguasaan membaca Alquran dan penguasaan metodologi dalam pengajaran Alquran sangat minim. Dalam arti, sebagian dari guru di Raudhatul Athfal ini belum mampu mencontohkan bacaan Alquran sesuai Ilmu Tajwid dan Fashahah untuk ditampilkan dalam Tilawatil Quran sebagaimana yang diharapkan.

Selanjutnya, permasalahannya adalah terdapat sebagian guru Raudhatul Athfal belum memiliki kompetensi yang sesuai dengan diharapkan dalam menguasai bacaan Alquran dengan menggunakan Tajwid, mereka masih kurang menguasai metode yang benar dan tepat dalam melaksanakan proses belajar mengajar Alquran di dalam kelas. Akibatnya, banyak di antara siswa Raudhatul Athfal yang juga kurang mampu membaca Alquran dengan fasih dan benar.
Menurut Thalib bahwa kompetensi guru dalam pembelajaran Alquran untuk anak-anak, pertama-tama ditekankan pada ketepatan mengucapkan huruf-huruf yang biasa disebut dengan makhorijul huruf. Sesudah ketepatan mengucapkan hurufhuruf, ditingkatkan kefasihan membaca kata dan kalimat, setelah itu ditingkatkan pada ilmu tajwid. Dengan demikian, pengajaran Alquran untuk anak-anak usia dini dapat mencapai kebutuhannya sampai pada tingkat kemahiran baca dengan tajwid. Membaca Alquran dengan bertajwid termasuk bagian upaya kita memuliakan Alquran. Rasulullah SAW selalu menganjurkan agar kita membaca Alquran dengan bertajwid (Thalib, 1991).

Peningkatan potensi dan kemampuan guru Raudhatul Athfal dalam penguasaan bacaan Alquran dan penguasaan dalam metode pembelajaran Alquran merupakan hal yang sangat penting dan sangat esensi terutama dengan kompetensi yang dimiliki, karena itu akan dapat menentukan pengembangan kompetensi siswa Raudhatul Athfal pada masa yang akan datang sebagai penerus generasi qurani. Berdasarkan kondisi ini maka penulis tertarik untuk melakukan penelitian terhadap guru-guru Raudhatul Athfal dalam mengajarkan Alquran pada anak usia dini. 
INTIQAD: JURNAL AGAMA DAN PENDIDIKAN ISLAM

ISSN 1979-9950 (print) || ISSN 2598-0033 (online), http://jurnal.umsu.ac.id/index.php/intiqad

DOI: 10.30596/intiqad.v12i1.4650

Vol. 12, No. 1 (June 2020)

\section{B. Metode Penelitian}

Penelitian ini dilakukan di Raudhatul Athfal Kota Medan. Alasan pemilihan lokasi penelitian karena institut tersebut telah melakukan pembelajaran Alquran khususnya untuk tingkat Raudhatul Athfal (RA). Sebagai subjek dalam penelitian adalah beberapa pihak yang terkait dengan pelaksanaan kompetensi guru dalam pembelajaran Alquran.

1. Kepala Kantor Kementerian Agama Kota Medan

2. Kasi Pendidikan Madrasah Kemenag Kota Medan

3. Kepala Raudhatul Athfal di Kota Medan

4. Guru yang bertugas sebagai guru Raudhatul Athfal di Kota Medan

Selanjutnya sebagai objek penelitian adalah pelaksanaan kompetensi guru dalam pembelajaran Alquran di Raudhatul Athfal (RA) Kota Medan.

Jenis penelitian ini adalah penelitian kualitatif. Strauss dan Corbin, mengatakan; penelitian kualitatif adalah jenis penelitian yang menghasilkan penemuan-penemuan yang tidak dapat dicapai dengan menggunakan prosedurprosedur statistik atau cara-cara lain dari kuantifikasi (Strauss \& Corbin, 2003). Alasan digunakannya pendekatan kualitatif adalah bahwa penelitian kualitatif dapat mengungkap fenomena-fenomena yang terjadi, sehingga menemukan dan memahami apa yang tersembunyi dibalik fenomena yang terjadi.

Pengumpulan data dalam penelitian ini dilakukan dengan 3 (tiga) teknik yang lazim dipergunakan dalam penelitian kualitatif, yaitu wawancara, observasi, dan pengkajian dokumen.

Teknik analisis data menggunakan teknik yang dikemukakan oleh Miles dan Huberman berikut :

a. Reduksi data, adalah membuat abstraksi seluruh data yang diperoleh dari catatan lapangan hasil observasi, wawancara dan pengkajian dokumen.

b. Penyajian data, adalah sekumpulan informasi tersusun yang memberi kemungkinan adanya penarikan kesimpulan dan pengambilan tindakan.

c. Simpulan, yaitu susunan data yang utuh, rinci dan mendalam berdasarkan data-data yang diperoleh dari hasil observasi, wawancara, dan pengkajian dokumen (Miles \& Huberman, 2002).

\section{Hasil dan Pembahasan}

Pembinaan kompetensi guru di Raudhatul Athfal yang dilaksanakan oleh Kementerian Agama Kota Medan dapat dikemukakan sebagai berikut: 
INTIQAD: JURNAL AGAMA DAN PENDIDIKAN ISLAM

ISSN 1979-9950 (print) || ISSN 2598-0033 (online), http://jurnal.umsu.ac.id/index.php/intiqad

DOI: 10.30596/intiqad.v12i1.4650

Vol. 12, No. 1 (June 2020)

\section{Program Peningkatan Kualifikasi}

\section{Pendidikan Guru}

Program peningkatan kualifikasi pendidikan guru adalah program peningkatan kualitas pendidikan bagi guru diperuntukkan bagi guru pendidikan keagamaan yang belum memiliki kualifikasi pendidikan minimal S-1 untuk mengikuti pendidikan $\mathrm{S}-1$ atau $\mathrm{S}-2$ pendidikan keguruan. Program ini berupa program kelanjutan studi dalam bentuk tugas belajar bagi guru yang memenuhi ketentuan yang diberlakukan.

\section{Program Pelatihan Terintegrasi}

\section{Berbasis Kompetensi}

Program pelatihan terintegrasi berbasis kompetensi adalah kegiatan pelatihan yang mengacu pada pembinaan kompetensi yang akan dicapai dan diperlukan oleh guru, sehingga isi atau materi pelatihan yang diberikan adalah gabungan atau integrasi bidang-bidang ilmu sumber bahan pelatihan yang secara utuh diperlukan untuk mencapai kompetensi guru. Guna meningkatkan profesionalisme guru perlu dilakukan pelatihan dan penataran yang intens pada guru. Pelatihan yang diperlukan adalah pelatihan yang disesuaikan dengan kebutuhan guru yaitu pelatihan yang mengacu pada tuntutan kompetensi guru.
3. Program Supervisi Pendidikan

Kementerian Agama Kota Medan dalam pelaksanaan supervisi untuk peningkatan kompetensi guru melaksanakan kepengawasan.

\section{Program}

Pemberdayaan

\section{Musyawarah Guru RA}

Kelompok Kerja Guru merupakan suatu forum atau wadah profesional guru (kelas/mata pelajaran) yang berada pada suatu wilayah kabupaten/kota/kecamatan/ sanggar/gugus sekolah, yang prinsip kerjanya adalah cerminan kegiatan dari, oleh dan untuk guru dari semua sekolah. Suatu organisasi nonstruktural yang bersifat mandiri, berasaskan kekeluargaan, dan tidak mempunyai hubungan hirarkis dengan lembaga lain. Penyusunan rencana pelaksanaan pembelajaran merupakan rancangan bagi guru Raudhatul Athfal untuk melaksanakan kegiatan pembelajaran. Rencana pelaksanaan pembelajaran tentunya sebelum pelaksanaan kegiatan pembelajaran dilaksanakan. Rencana pembelajaran yang disusun oleh guru Raudhatul Athfal harus mengacu kepada karakteristik anak yaitu usia, sosial budaya dan kebutuhan individual anak. Oleh karena itu bagi guru Raudhatul Athfal dalam menyusun rencana pelaksanaan pembelajaran harus memperhatikan tujuan. Yaitu: 
INTIQAD: JURNAL AGAMA DAN PENDIDIKAN ISLAM

ISSN 1979-9950 (print) || ISSN 2598-0033 (online), http://jurnal.umsu.ac.id/index.php/intiqad

DOI: 10.30596/intiqad.v12i1.4650

Vol. 12, No. 1 (June 2020) a. Mendukung pencapaian Kompetensi Dasar dan Kompetensi Inti.

b. Mendukung

keberhasilan pengelolaan pembelajaran yang bermakna.

c. Mengarahkan guru dalam menyiapkan alat dan bahan yang diperlukan.

d. Mengarahkan guru untuk membangun sikap, pengetahuan dan keterampilan yang diharapkan dimiliki anak.

e. Mendukung keberhasilan pelaksanaan pembelajaran.

Metode pembelajaran adalah cara yang digunakan pendidik dalam melakukan kegiatan pembelajaran kepada anak untuk mencapai kompetensi tertentu.

Metode pembelajaran Alquran yang dilaksanakan kepada anak di Raudhatul Athfal Kota Medan dengan melakukan langkah-langkah yaitu:

1) Pengenalan huruf, guru mengajarkan huruf dari alif sampai ya dengan menghafalkan satu persatu huruf hijaiyah yang diikuti oleh anak didik serta menghafalnya perlahan-lahan, dan menuliskannya dengan huruf yang mudah dipahami anak-anak. Sehingga anak usia dini selain cepat menghafal, mereka juga akan selalu ingat huruf yang dilafalkan. Misalnya 1

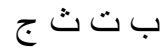

2) Pengenalan harakah, dengan menuliskan baris atas, bawah, dan sukun, serta mengajak menghafalnya

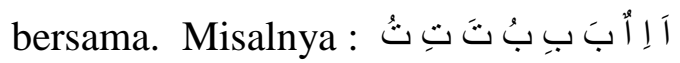

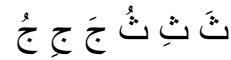

3) Penyambungan huruf, yakni menjelaskan dan mengajarkan hurufhuruf yang disambung antara satu dengan lainnya.

4) Pengenalan panjang pendek, yakni menjelaskan bacaan-bacaan mana yang dibaca panjang dan bacaan yang dibaca pendek.

5) Pengenalan kalimat, yakni menjelaskan penggalan-penggalan kata bahasa Arab atau kata yang dikutip dari Alquran.

6) Pengenalan tanda waqaf, yakni menjelaskan tanda-tanda berhenti (waqaf), seperti tanda wajib berhenti ketika ada huruf a ) waqaf lazim); tidak boleh berhenti pada huruf $\forall$, dan sebagainya

Adapun kendala pelaksanaan pembelajaran Alquran di Raudhatul Athfal Kota Medan, masih mengalami kendala rendahnya kualitas guru dan terbatasnya sarana/prasarana untuk kegiatan pembelajaran. Permasalahan lainnya adalah pembelajaran yang monoton dan berfokus 
INTIQAD: JURNAL AGAMA DAN PENDIDIKAN ISLAM

ISSN 1979-9950 (print) || ISSN 2598-0033 (online), http://jurnal.umsu.ac.id/index.php/intiqad

DOI: 10.30596/intiqad.v12i1.4650

Vol. 12, No. 1 (June 2020) pada guru, minimnya alat peraga dan buku pegangan untuk bahan ajar.

Permasalahan-permasalahan tersebut harus menjadi perhatian utama untuk memulai perbaikan penyelenggaraan pendidikan bagi anak usia dini.

Beberapa upaya yang sudah dilakukan dalam mengatasi kendala pembelajaran Alquran di Raudhatul Athfal Kota Medan adalah dengan meningkatkan kompetensi guru melalui pelaksanaan pelatihan keterampilan pembelajaran Alquran. Disamping itu juga dilakukan upaya pemenuhan terhadap saran dan prasarana yang dibutuhkan selama pelaksanaan pembelajaran Alquran di Raudhatul Athfal Kota Medan.

\section{Simpulan}

1. Perencanaan Kegiatan Kementerian Agama Kota Medan untuk meningkatkan kompetensi guru dalam mengajarkan Alquran di Raudhatul Athfal Kota Medan yaitu program peningkatan kualifikasi pendidikan guru, program pelatihan terintegrasi berbasis kompetensi, program supervisi pendidikan dan program pemberdayaan musyawarah guru RA.
2. Perencanaan pembelajaran guru Raudhatul Athfal dalam mengajarkan Alquran di Raudhatul Athfal Kota Medan yaitu rencana penyusunan atau pengorganisasian bahan-bahan pembelajaran yang akan diberikan/diajarkan kepada siswa yang terdiri dari rencana penyusunan Program Semester (PROMES), Rencana Pelaksanaan Pembelajaran Mingguan (RPPM), Rencana Pelaksanaan Pembelajaran Harian (RPPH), dan Standar Operasional Prosedur (SOP)

3. Metode pembelajaran Alquran yang digunakan guru secara umum yaitu metode Iqro' yang terdiri dari pengenalan huruf, pengenalan harakah, penyambungan huruf, pengenalan panjang pendek, dan pengenalan kalimat, pengenalan tanda waqaf.

4. Kendala dalam pelaksanaan pembelajaran Alquran yaitu rendahnya kualitas guru dan terbatasnya sarana/prasarana untuk kegiatan pembelajaran Alquran di Raudhatul Athfal Kota Medan.

5. Upaya guru dalam mengatasi hambatan dalam mengajarkan Alquran di Raudhatul Athfal Kota. 
INTIQAD: JURNAL AGAMA DAN PENDIDIKAN ISLAM

ISSN 1979-9950 (print) || ISSN 2598-0033 (online), http://jurnal.umsu.ac.id/index.php/intiqad

DOI: 10.30596/intiqad.v12i1.4650

Vol. 12, No. 1 (June 2020)

6. Medan dengan meningkatkan

kompetensi guru melalui pelaksanaan pelatihan keterampilan pembelajaran Alquran dan pemenuhan terhadap saran dan prasarana yang dibutuhkan selama pelaksanaan pembelajaran Alquran di Raudhatul Athfal Kota Medan.

\section{E. Daftar Pustaka}

Cholil, M. (1991). Kembali Kepada Alquran dan As-Sunnah. Jakarta: Bulan Bintang.

Djamarah, S. B. (2003). Guru Dan Anak Didik Dalam Interaksi Edukatif. Jakarta : Rineka Cipta.

Miles, M. B., \& Huberman, A. M. (2002). Analisis Data Kualitatif. (T. R. Rohidi, Trans.) Jakarta: UI-Press.

Rivai, V., \& Murni, S. (2010). Education Management Analisis Teori dan Praktik. Jakarta: Rajawali Press.

Sagala, S. (2012). Kemampuan

Profesional Guru dan Tenaga Kependidikan. Bandung: Alfabeta.

Strauss, A., \& Corbin, J. (2003). Dasardasar Penelitian Kualitatif. (A. Hakim, Trans.) Yogyakarta: Pustaka Pelajar.
Sugiyono. (2008). Metode Penelitian

Pendidikan, Pendekatan

Kuantitatif, Kualitatif, dan $R \& D$.

Bandung: Alfabeta.

Sutisna, O. (2003). Administrasi

Pendidikan Dasar Teoritis Untuk

Praktek Profesional. Bandung:

Angkasa.

Sutisna, O. (2003). Administrasi

Pendidikan Dasar Teoritis Untuk

Praktek Profesional. Bandung:

Angkasa.

Thalib, M. (1991). 50 Pedoman Mendidik

Anak Menjadi Anak Shaleh.

Bandung: Irsyad Baitussalam.

Uhbiyati, N. (2005). Ilmu Pendidikan Islam (IPI) Untuk IAIN, STAIN. Bandung: Pustaka Setia. 